\title{
CREATION OF THE IMPLEMENTATIVE CONDITIONS OF INFORMATION TECHNOLOGIES IN HIGHER EDUCATION INSTITUTIONS
}

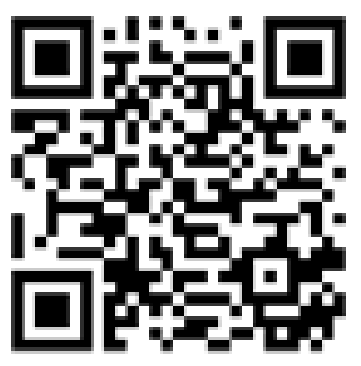

To cite this article:

\author{
Nataliia Pyzh, PhD \\ Instructor, Phonetics and Practice of English Chair \\ Kyiv National Linguistic University \\ Kyiv, Ukraine \\ pyzhykpyzh@meta.ua \\ https://0000-0003-0311-5471 \\ Tetiana Halenko, Master in Language and Literature. \\ Philologist-researcher. Lecturer of English and German \\ and Foreign Literature \\ Kyiv, Ukraine \\ tatiana@galenko.org \\ https://0000-0003-2131-7157
}

Pyzh, N., Halenko, T. (2021). Creation of the implementative conditions of information technologies in higher education institutions. Education: Modern Discourses, (4), 116-121.

https://doi.org/10.37472/2617-3107-2021-4-11

\begin{abstract}
Thepaperhighlights the problems of the implementation of information technologies into the professional activity of teachers in higher education institutions. Further integration of the country into the world economic and cultural space encourages the synchronization of the Ukrainian education with the global trends, taking into account IT development. The potential directions for the development of higher education digitalization have been identified. One of the main directions of higher education institution activity - modelling and expansion of information and communication educational environment is specified. The author outline the conditions of information and communication learning environment contributing to the increase the digital competence of teachers - IT knowledge, IT skills and readiness to use the achievements of informatiszation process in their professional activities. Basing on the analysis of the main IT development trends in the educational sphere, the authors have formulated proposals to improve the professional activity of teachers and to implement information technologies into the Ukrainian higher education institutions in compliance with the transformations currently taking place in the modern world.
\end{abstract}

Keywords: digital competence; educational environment; educational process; higher education institution; information technology; informatization.

\section{INTRODUCTION. PROBLEM STATEMENT}

In the context of informatization of society, Ukraine cannot stay away from this global tendency that exists as a factor in the development of education. The formation of a modern legal, economic and informational space in Ukraine actualizes the need for constant updating of professional knowledge and skills of specialists, their readiness for the professional growth. 
One of the most important modern ways is the usage of intensive information technology (IT) aimed at creating the conditions for implementation of continual professional improvement throughout the live of specialists.

Information technology, as a global multicomponent technology innovation which has sustainable development, is a complex and indispensable subject to study and nowadays has become a key systematic factor in the development of a modern educational system. This assumption can be made by analysing the educational system from the standpoint of the demand for:

- publicity of highly qualified specialists with different occupation, who are capable to work in the conditions of society full of digitalization;

- an educational system of pedagogical workers, who are capable of using logically IT technologies in their professional field with the aim of improving the quality of education;

- pedagogical workers from the view of the need to introduce new teaching methods through the usage of IT technologies;

- students in order to obtain the quality knowledge, skills and abilities; realization of their personal potential in the process of preparation the future professional activity in the conditions of educational digitalization (Gurzhiy et. al., 2013; Kartashova, 2012).

Further integration of the country into the world economic and cultural space encourages the synchronization of the Ukrainian education with the global standards. Therefore, it is understandable that the steps of implementations of IT content and development of methodology for training competent specialists will lead to positive changes.

\section{LITERATURE REWIEW}

The ideas of IT introduction in education are not new, there are a lot of research studies which are devoted to this topic, i.e. works of V. Bykov (Bykov, 2019), A. Gurzhiya (A. Gurzhiy, L. Kartashova \& V. Lapinskyi, 2013), M. Karpenko (M. Karpenko, 2014), L. Kartashova (Kartashova, 2015) and others. The topicality of the problem of digital competence development of teachers in higher education institutions (HEI) is conditioned by the needs of the society in advance education, continuous increase of information load and the need for their professional and personal development. In the context of dynamic socio-economic processes, increasing the flow of professional information which is required for professional activity, the modern pedagogue must continuously increase the level of his professional knowledge, in particular through the active usage of IT as a means, forms and methods of activity.

The above makes it possible to identify potential trends in the digitalisation of higher education (Bykov, 2019; Proekt Tsyfrova adzhenda Ukrainy, 2016).

- formation of digital competence of teachers in HEI as a basis for updating aspects of professional activity;

- formation of high level of culture competences of teachers;

- introduction of the achievements of society digitalization into the practice of teaching subjects in HEI;

- implementation of the achievements of society digitalization in the management of the educational process;

- dynamic and sustainable improvement of IT teaching in accordance with the state of modern development of society digitalization.

In recent years, the introduction of IT is the most relevant in such areas of higher education as educational and methodological support of teaching process and management of the educational process where the creation of the implementative conditions of IT in HEI educational activities represents a demand. 


\section{METHODOLOGY}

The authors applied the method of analysis of the research papers of the Ukrainian scholars V. Bykov (Bykov, 2019), A. Gurzhiy (A. Gurzhiy, L. Kartashova \& V. Lapinskyi, 2013), M. Karpenko (M. Karpenko, 2014), L. Kartashova (Kartashova, 2015) and of regulatory documents/materials (Proekt Tsyfrova adzhenda Ukrainy - 2020). The findings of the analysis provided the development of the proposals to improve the professional activity of teachers in the area of implementing the IT into the Ukrainian HEI in compliance with the transformations currently taking place in a modern world.

\section{MAIN RESULTS}

For the purpose of realization of the mentioned directions of digitalization of higher education, we will distinguish one of the activity directions of higher education institution (HEI), namely - modelling and expansion of information, educational and communicative environment. What, in turn, are formed of such priority tasks:

- establishment of system requirements for the pedagogical composition regarding the level of knowledge, skills in IT;

- development of conceptual provisions for the implementation of the modern achievements of science and technology in the educational process;

- directing pedagogical activities to form personal readiness for IT implementation to the educational process and accumulating experience of independent work.

Analytical review of the professional activity of the HEI pedagogues shows that the involvement of IT in the educational process, training using electronic educational resources (EER), the use of multimedia educational programs are often used by pedagogues to build students' interest in gaining the knowledge (Kartashova, 2015). The survey shows that, for the most part, pedagogues use IT as a means of communication - using about $100 \%$ of Internet resources, online communication and correspondence can be included here. Likewise, applications are densely used $-99 \%$ of pedagogues use them as a tool for preparing for classes, namely: preparation of lecture material, clarity, creation of presentations, etc. (see Fig. 1.).
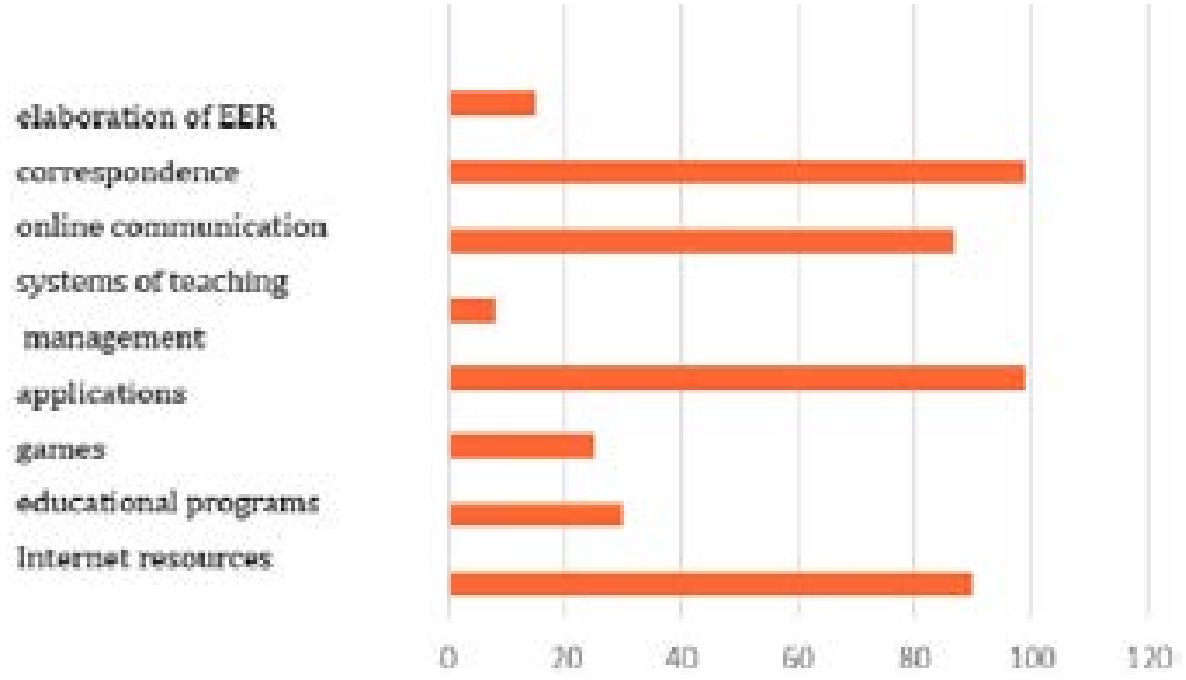

Fig. 1.

Results of questionnaire of HEI teachers concerning the usage of IT resources and tools in their professional activity (in \%)

Source: Kartashova, 2015. 
More complicated situation with the usage of software that is designed to manage the educational process - only $8 \%$ confirmed that they not only know the purpose of such tools, but they also use these tools in their professional activities both online and offline. This category of pedagogues demonstrates not only an appropriate level of IT knowledge, skills, but also a high level of competencies that allow them to develop personal EER and to use it, among others (only 15\% of pedagogues), the developed and offered professional EERs. They are also able to classify EERs, define their goals, set tasks and flexibly adapt their functionality to their needs and educational process requirements.

Such teachers, who have profound knowledge in IT achievements, are distinguished by their ability to build the educational process into a logical, structured and accessible way; as a rule, they are quite successful in operating interesting information from the Internet, which captures students with a broad outlook and a high level of education.

So, extremely important not only a teacher to have a high-level IT skills, but also to find a place and value in the educational process. In addition, the modern erudite teacher who demonstrates to students IT in a new level quality thereby opens a psychological mechanism of inheritance.

The need for qualitative, progressive changes in the HEI and modernization of the education system, which necessitate its improvement in the direction of intensive, continuous training of teachers for IT activities, will be generated by one of the ways, for instance, by informational-motivational support for teachers to acquire independent knowledge, which consists of composing the conditions for their creativity.

We see the realization of the support of the educational process by:

- teacher's search and selection of the pedagogically appropriate IT forms, methods and teaching aids;

- adaptation of IT training, according to: content of discipline, formation of relevant competences, stimulation of cognitive and educational activities of students;

- formation of personal educational environment, the conditions of which contribute to the acquisition of subject knowledge, which become the basis for solving real life and professional problems;

- focusing on the achievement of the educational processes goals in the choice of IT tools for determining the level of educational achievement.

One of the obvious problems is the creation of appropriate conditions in the HEI prior to IT implementation, namely, the creation of an information and educational environment. It is not about improving the individual characteristics or organization of a particular environment for the activities of pedagogues, but about the problem of the educational system as a whole: goals, content, methods, tools, forms and technologies of teaching, etc. After all, teachers in the environment of the HEI should be able to:

- continuous access to IT resources;

- use of a wide range of electronic educational materials and obtain information about them;

- develop and use electronic educational tools that provide appropriate digital tools;

- organizing distance teaching of students and self-study on relevant Internet resources.

An indispensable condition is the actualization of conscious mastery of IT for the purpose of pedagogical self-organization and self-improvement of knowledge. This points to the particular importance of considering the characteristics and capabilities of each teacher as an individual - namely individual characteristics and subjective experience. It's important to mention that the improvement of IT knowledge and IT skills should be carried out in the course of professional activity and be permanent (Bykov, 2019; Karpenko, 2014; Kartashova, 2015). 
Accordingly, we propose to distinguish the following conditions.

1. Structuring the content of educational and methodological material in accordance with the goals in the form of electronic educational and methodological complexes in specialized disciplines. Their content should vary depending on the level of professional and digital competence. A fundamental approach to teaching material is the requirement for entry-level IT skills. In general, e-learning complexes should contain the following blocks: professionalinformational, professional-practical, informational-reference and communicative-controlling.

2. Selection of forms and methods of training aimed at activating cognitive activity through solving problems of a problematic nature in order to develop skills in making effective pedagogical decisions.

3. Use of interactive distance learning tools to develop creative abilities: interactive video lectures and training games. The essence of video lectures is the organization of interaction in different types of professional communication, the development of communicative aspects of improving the professional activity of the teacher. Training games are used to consolidate practical skills in accordance with the content of the teaching material. The organization of communication during distance learning provides an opportunity for participants of the educational process to exchange experience of solving professional problems.

4. Organization and continuous holding of seminars aimed at IT-methodological training of HEI teachers The subject of increased attention in this aspect is the issue of the structure of electronic information materials, the organization of video lectures and presentations, the content of information resources, the definition of their didactic capabilities, the development of rules for their use depending on the learning objectives, as well as the organization of ongoing and final control of the student's knowledge.

Given the rather rapid development of IT, the development of information and education environment for HEIs should be one of the goals of providing an "outrunning" effect: its content should be formed so that teachers have access to tools that allow it to be adjusted. The delay in updating educational information, making changes to the methods and forms of its presentation, significantly reduces the motivation for using IT.

\section{CONCLUSIONS}

The problem of forming an information and educational environment of the HEI is a multidimensional organizational and economic task that has to be solved today. However, it should be acknowledged that this task cannot be completed - it can take some stage, according to the informatization of the educational process. The problem of preparing and educating higher education teachers for activities in an information and educational environment involves assessing the effects that are expected in the near future and anticipating the longterm consequences.

Moreover, filling the information and educational environment with educational material, adjusting its management system, adhering to the specified conditions and expanding their list, dramatically changes the organizational and technological equipment of the educational process and leads to positive changes in the quality of education.

Consequently, the priority tasks were formed to provide the establishment of system requirements for the pedagogical composition regarding the level of knowledge, skills in IT, the development of conceptual provisions for the implementation of the modern achievements of science and technology in the educational process, the directing pedagogical activities to form personal readiness for IT implementation to the educational process and accumulating experience of independent work. 


\section{REFERENCES}

Bykov, V. (2019). Dosvid: Tsyfrove navchalne seredovyshche. In O. V. Ovcharuk (Ed.), Tsyfrova kompetentnist suchasnoho vchytelia novoi ukrainskoi shkoly: zbirnyk tez dopovidei uchasnykiv vseukrayinskoho naukovo-praktychnoho seminaru (Kyiv, 12 bereznia 2019 r.). Instytut informatsiinykh tekhnolohii I zasobiv navchannia NAPN Ukrainy. https:// lib.iitta.gov.ua/715564/1/Tsyfrova\%20kompetentnist\%20suchasnoho\%20vchytelia\%20 novoi\%20ukrainskoi\%20shkoly\%202019.pdf

Gurzhiy, A. M., Kartashova, L. A. \& Lapinskyi, V. V. (2013). IT-hotovnist vchyteliv inozemnykh mov: metodolohiia, teoriia, tekhnolohii: navchalnyi posibnyk. Instytut obdarovanoi dytyny.

Karpenko, M. (2014). Rozvytok dystanzyynogo navchannya yak vidpovid na suchasni vyklyky dlya Ukrainy. Stratehichni priorytety, 4(33), 102-105. https://scholar.google. com.ua/citations?view op=view citation\&hl=uk\&user=U44P9I8AAAAJ\&citation for view=U44P9I8AAAAJ:IjCSPb-OGe4C

Kartashova, L. (2012). Elektronyy osvitniy resurs yak zasib pidtrymky navchannya informaziynyh technologiy maybutnih filologiv. Problemy suchasnoho pidruchnyka, 12, 421-427. https://ib.iitta.gov.ua/4165/

Kartashova, L. (2015). Informazyyno osvitnye seredovyshe Ayti innovaziya dlya profesiyno technichnyh zakladiv Ukrayiny. In M. M. Koziar \& N. H. Nychkalo (Eds.), Informazyinokomunikaziyni tehnologiyi: dosvid, problemy, perspectyvy. Zbirnyk naukovykh prats. Chastyna I. (pp. 30-35).

Proekt Tsyfrova adzhenda Ukrainy - 2020 («Tsyfrovyi poriadok dennyi» - 2020) Kontseptualni zasady (versiia 1.0) (2016). Retrieved November 16, 2021, from https://ucci.org.ua/uploads/ files/58e78ee3c3922.pdf 